(c) American Dairy Science Association, 2004.

\title{
Gelation of Casein-Whey Protein Mixtures
}

\author{
Astrid J. Vasbinder, ${ }^{1}$ Fred van de Velde, ${ }^{1,2}$ \\ and Cornelis G. de Kruif ${ }^{1,3}$ \\ ${ }^{1} \mathrm{NIZO}$ Food Research, Product Technology Department, \\ Kernhemseweg 2, P.O. Box 20, 6710 BA Ede, \\ The Netherlands (www.nizo.com) \\ ${ }^{2}$ Wageningen Centre for Food Sciences, \\ P.O. Box 557, 6700 AN Wageningen, The Netherlands \\ ${ }^{3}$ Van 't Hoff Laboratory, Debye Research Institute, \\ University of Utrecht, Padualaan 8, $3584 \mathrm{CH}$, Utrecht, The Netherlands
}

\section{ABSTRACT}

Heated milk consists of a mixture of whey proteincoated casein micelles and soluble whey protein aggregates. The acid-induced gelation properties of heated milk are consistently different from those of unheated milk-i.e., a shift in gelation $\mathrm{pH}$, stronger gels, and a different microstructure of the gels. In this study we investigated the role of the different fractions of denatured whey proteins on the acid-induced gelation, the gel hardness, and the microstructure. Both whey protein fractions contribute to the observed shift in gelation $\mathrm{pH}$, although by a different mechanism. Obtaining gels with high gel hardness occurs most effectively when all denatured whey proteins are present as whey protein aggregates. It was observed that disulfide bridge exchange reactions during the acid-induced gelation at ambient temperature play an important role for both whey protein fractions. Additionally, disulfide interactions seem to occur between the aggregates and the casein micelles during the gel state. In this study, we show the development of a new approach for confocal scanning laser microscopy measurements-i.e., separate staining of the proteins in milk. By using this method, we were able to determine that, although whey protein aggregates are not linked to the casein micelles, they nevertheless gel at the same moment. This work adds to a better understanding of the role of denatured whey proteins during acid-induced gelation and could improve the effective use of whey proteins.

(Key words: casein micelle, whey protein, structure analysis, confocal scanning laser microscopy)

Abbreviation key: CSLM = confocal scanning laser microscopy, DWS = diffusing wave spectroscopy,

Received: May 21, 2003.

Accepted: November 3, 2003.

Corresponding author: C. G. de Kruif; e-mail: Kees.de.Kruif@ nizo.nl.
GDL $=$ glucono- $\delta$-lactone, $\mathbf{N E M}=\mathrm{N}$-ethylmaleimide, $\mathbf{W P F}=$ whey protein free, $\mathbf{W P I}=$ whey protein isolate .

\section{INTRODUCTION}

Heating milk is an essential step in the processing of various dairy products. It leads to desirable properties of the final product, such as an increased viscosity of yogurt. The properties of milk are considerably changed during heating due to heat-induced denaturation of the whey proteins. Upon denaturation, the whey proteins either form soluble whey protein aggregates or associate with the casein micelles, resulting in whey proteincoated casein micelles (Singh et al., 1996; Oldfield et al., 2000; Vasbinder et al., 2003b).

During acidification or fermentation of milk, the casein micelles start to aggregate when the $\mathrm{pH}$ approaches its isoelectric point (pI). In unheated milk, the casein micelles flocculate at $\mathrm{pH} 4.9$. Coating of the casein micelles with whey proteins changes the surface properties. The isoelectric $\mathrm{pH}$ of whey proteins is at $\mathrm{pH}$ 5.2. Therefore, surface-coated casein micelles will flocculate at higher $\mathrm{pH}$, resulting in a clear shift in gelation $\mathrm{pH}$ (Heertje et al., 1985; Horne and Davidson, 1993; Lucey et al., 1997; Vasbinder et al., 2001). Large and small deformation rheological studies showed that heated milk gels had an increased gel hardness (Dannenberg and Kessler, 1988) and storage modulus compared with unheated milk gels (van Vliet and Keetels, 1995; Lucey et al., 1998a; Vasbinder et al., 2003c). A significant part of the increased gel hardness was caused by disulfide bridge formation during the gel state at ambient temperatures (Vasbinder et al., 2003c). It is generally known that acidic conditions are not favorable for the formation of thiol-disulfide bond exchange reactions. Recently, the formation of these bonds and their effect on the mechanical properties of the gel was demonstrated for acid-induced cold-set gels of whey proteins (Alting et al., 2000) and casein micelles (Vasbinder et al., 2003c). The occurrence of this thioldisulfide bond exchange reaction under less favorable 
acidic conditions is probably enabled by the proximity of the protein-building particles in the protein gel network formed after diminishing of the electrostatic repulsion near the isoelectric point of the proteins. The microstructure of gels made from unheated milk had a tortuous clustered network, whereas gels of heated milk showed a branched microstructure with clearly defined pores (Lucey et al., 1998b). Surprisingly, these observed differences in microstructure did not affect the permeability of the gels (van Vliet and Keetels, 1995; Lucey et al., 1998b).

Concluding, whey protein denaturation is of prime importance for the gelation kinetics and final gel properties of heat-treated milk. Most studies have focused on total whey protein denaturation, and only limited work has been done on the effect of how the whey proteins were distributed. The influence of denatured whey protein-i.e., aggregates versus coating-on gelation processes was studied by Lucey et al. (1998a) and Schorsch et al. (2001). Both studies revealed a clear effect of the whey proteins distribution on the gelation properties.

In this study we selected 4 milk systems consisting of whey protein-free (WPF) milk and whey proteins present in different forms. The concentrations of both proteins were comparable to those in fresh milk. The first system consisted of WPF milk with added native whey proteins. The second system was obtained by heating the first system. This heated milk consisted of a mixture of soluble whey protein aggregates (30\%) and whey proteins coating the casein micelles (70\%) as determined in a previous study (Vasbinder et al., 2003b). Two additional model systems were developed having either all the whey proteins present in soluble aggregates or as a coating on the casein micelles. These 2 model systems allow us to study the role of each of the fractions (aggregates vs. coating) of whey proteins present in heated milk. Our approach to studying these systems is new compared with other papers investigating these phenomena in the following aspects. We studied the gelation kinetics by the use of diffusing wave spectroscopy (DWS), a light-scattering method very suitable for monitoring the mobility of particles in turbid systems like milk in a completely undisturbed manner (Vasbinder et al., 2001). The gel properties were investigated by large deformation studies in the absence and presence of N-ethylmaleimide (NEM), a chemical compound preventing the formation of disulfide bridges during the gel state. This allowed us to study the disulfide-bridge-forming properties of the different whey protein fractions. The microstructure of the gels was studied by confocal scanning laser microscopy (CSLM), in which we stained the casein micelles and whey proteins with different stains, allowing us to study the role of the 2 fractions independently. Additionally, we varied the concentration of whey proteins in order to obtain more information on the role of the different whey protein fractions.

\section{MATERIALS AND METHODS}

\section{Preparation of Whey Protein-Free Reconstituted Skim Milk}

Whey protein-free (WPF) reconstituted skim milk was prepared at a concentration of $8.8 \%$ (wt/wt) from WPF milk powder prepared by ultra- and micro-filtration (NIZO food research, Ede, The Netherlands; 0.02\%, wt/wt, native whey proteins). The milk was stirred at $45^{\circ} \mathrm{C}$ for $1 \mathrm{~h}$. To prevent bacterial growth, $0.02 \%$ sodium azide was added, and the milk was kept overnight at $4^{\circ} \mathrm{C}$ before use. The initial $\mathrm{pH}$ of the WPF milk was $6.67( \pm 0.01)$.

\section{Whey Protein Isolate Solution}

Whey protein isolate (WPI) solution (Bipro; Davisco Food International Inc., Eden Prairie, MN) was prepared at a concentration of $9 \%(\mathrm{wt} / \mathrm{wt}$ ) and at its natural $\mathrm{pH}-$ i.e., 7.5. The solution was stirred for $2 \mathrm{~h}$ at room temperature and subsequently filtered though a 0.45 $\mu \mathrm{m}$ filter; $0.02 \%$ (wt/wt) $\mathrm{NaN}_{3}$ was then added. Heating this solution for $2 \mathrm{~h}$ at $68.5^{\circ} \mathrm{C}$ led to the formation of aggregates with an average hydrodynamic diameter of $62 \mathrm{~nm}$, which was determined by dynamic light scattering (Alting et al., 2000).

\section{Milk Systems}

Different milk systems were prepared by mixing 19.45 parts of WPF milk and 1 part of WPI solution. The cas/wheynative system was prepared by mixing WPF milk and unheated WPI solution. The cas/whey ${ }_{\text {coat }}$ system was prepared by heating the cas/wheynative system at $\mathrm{pH} 6.55$ for $10 \mathrm{~min}$ at $90^{\circ} \mathrm{C}$. The cas/whey ${ }_{\text {aggr }}$ system was prepared by mixing WPF milk with WPI aggregates without any further treatment. The fourth sys-

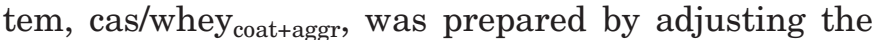
cas/whey native $_{\text {system to }} \mathrm{pH} 6.7$ and subsequent heating for $10 \mathrm{~min}$ at $90^{\circ} \mathrm{C}$. The whey protein compositions of these mixtures were determined by capillary electrophoresis (Vasbinder et al., 2003b). The conditions used and the whey protein composition of the 4 systems are presented in Table 1. Variations in whey protein concentrations were obtained by mixing $0,0.25,0.5$, and 0.75 part of WPI solution with, respectively, 1.0, 0.75, 0.5 , and 0.25 parts of water in order to obtain 1 part of WPI solution, which is mixed with the WPF milk (19.45 parts), resulting in concentrations of $0.11,0.22$, 
Table 1. The preparation and whey-protein composition of the four milk systems. In column 2, the way in which the whey proteins were initially added to the whey protein free (WPF)-milk is shown. Column 3 shows to which pH the WPF-milk with the whey proteins was subsequently adjusted, and column 4 shows the heat treatment that was performed on these samples. In columns 5 and 6 , the determined ratio of whey proteins associated with the casein micelles and present in whey protein aggregates is shown.

\begin{tabular}{lllllc}
\hline & $\begin{array}{l}\text { Form in } \\
\text { which whey } \\
\text { proteins are } \\
\text { initially added }\end{array}$ & $\mathrm{pH}$ & $\begin{array}{l}\text { Heat } \\
\text { treatment }\end{array}$ & $\begin{array}{l}\text { \% Whey protein } \\
\text { associated with } \\
\text { casein micelle }\end{array}$ & $\begin{array}{l}\text { \% Whey protein } \\
\text { present in } \\
\text { aggregate }\end{array}$ \\
\hline Cas/whey $_{\text {native }}$ & Native & 6.7 & - & 0 & 0 \\
Cas/whey & Aggregate & 6.7 & - & 0 & 100 \\
Cas/whey & Native & 6.55 & $10 \mathrm{~min}, 90^{\circ} \mathrm{C}$ & $100^{1}$ & 0 \\
Cas/whey $_{\text {aggr+coat }}$ & Native & 6.7 & $10 \mathrm{~min}, 90^{\circ} \mathrm{C}$ & $70^{2}$ & $30^{2}$ \\
\hline
\end{tabular}

${ }^{1}$ Vasbinder et al., 2003a.

${ }^{2}$ Vasbinder et al., 2003b.

0.33 , and $0.44 \%$ WPI in the milk. Heat treatment was performed in glass tubes (volume $8 \mathrm{~mL}$, diameter $1 \mathrm{~cm}$ ) containing $5 \mathrm{~mL}$ of milk and closed with a screw cap. After heat treatment for $10 \mathrm{~min}$ at $90^{\circ} \mathrm{C}$, the tubes were cooled with tap water to room temperature.

\section{Acid-Induced Gelation}

The milk systems, as described above, were equilibrated for $2 \mathrm{~h}$ at $20^{\circ} \mathrm{C}$ and subsequently for $75 \mathrm{~min}$ at $32^{\circ} \mathrm{C}$. N-ethylmaleimide (NEM) was added to the milk in a final concentration of $5 \mathrm{~m} M$ prior to acidification. After addition of glucono- $\delta$-lactone (GDL; $1.2 \%$, wt/wt), the milk was stirred gently for $2 \mathrm{~min}$ and incubated at $32^{\circ} \mathrm{C}$. The $\mathrm{pH}$ was followed with time, and the milk systems reached a $\mathrm{pH}$ of about 4.6 after approximately $24 \mathrm{~h}$ of incubation.

\section{Diffusing Wave Spectroscopy (DWS)}

The clotting of the milk during acidification was monitored by DWS. Light from a 5-mW He-Ne laser (632.8 $\mathrm{nm}$ ) was passed through a multimode fiber into the milk. The back-scattered light was monitored by a single-mode fiber located at $3.0 \mathrm{~mm}$ from the input fiber. The scattered light was detected with a photo multiplier tube (ALV SO-SIPD) and fed into a PC interfaced autocorrelator (Flex 5000, correlator.com). The time at which the autocorrelation curve has decayed to $50 \%$ of its maximum plateau level is defined as $\tau_{1 / 2}$ (Vasbinder et al., 2001). The correlation functions were monitored with time at intervals of $2 \mathrm{~min}$. All data were normalized by the $\tau_{1 / 2}$ value (the average of 5 measurements) of the same sample prior to GDL addition, eliminating variations between the fibers.

\section{Gel Hardness}

Gel hardness was determined with a texture analyzer (type TA-XT2, Stable Micro Systems Ltd., Godalming,
England). The acidification took place in a crystallizing dish containing $100 \mathrm{~g}$ of milk. After $24 \mathrm{~h}$ of incubation at $32^{\circ} \mathrm{C}$, the acid-induced gels were penetrated with a wire mesh-device at $20^{\circ} \mathrm{C}$. The mesh consisted of 4 blades $(45 \times 1.5 \times 2 \mathrm{~mm})$ of stainless steel arranged in a double cross. A force-time curve was obtained at a crosshead speed of $0.3 \mathrm{~mm} \mathrm{~s}^{-1}$ for a $10-\mathrm{mm}$ displacement, and gel hardness was expressed as the force (g) at the maximum of the force-time curve (Bourne, 1978).

\section{Confocal Scanning Laser Microscopy}

Protein-reactive succinimidyl ester derivatives of fluorescent probes (Molecular Probes Inc., Eugene, OR) were selected for the covalent labeling of the milk proteins. The WPF milk was covalently labeled with Texas Red-X carboxylic acid succinimidyl ester, and WPI solutions and WPI aggregate dispersions were covalently labeled with Oregon Green 488 carboxylic acid succinimidyl ester. The labeling experiments were performed using the procedures as described by Haugland (2002). Fractions of unreacted fluorescent probes were below $20 \%$ of the starting material, and solutions were used without further purification.

Confocal scanning laser microscopy images were recorded at NIZO food research on a Leica TCS SP Confocal Scanning Laser Microscope, equipped with an inverted microscope (model Leica DM IRBE), used in the single-photon mode with an $\mathrm{Ar} / \mathrm{Kr}$-visible light laser. A Leica 63x/UV/1.25NA/water-immersion/PL APO objective lens was used. The excitation wavelengths were 488 and $568 \mathrm{~nm}$, respectively, for Oregon Green and Texas Red; corresponding emission maxima were at 521 and $603 \mathrm{~nm}$ (Haugland, 2002). Digital image files were acquired in multiple tif formats and in $1024 \times$ 1024 pixel resolution.

\section{RESULTS AND DISCUSSION}

In this study we used 4 casein-whey protein systems that contained whey proteins in different forms-i.e., 


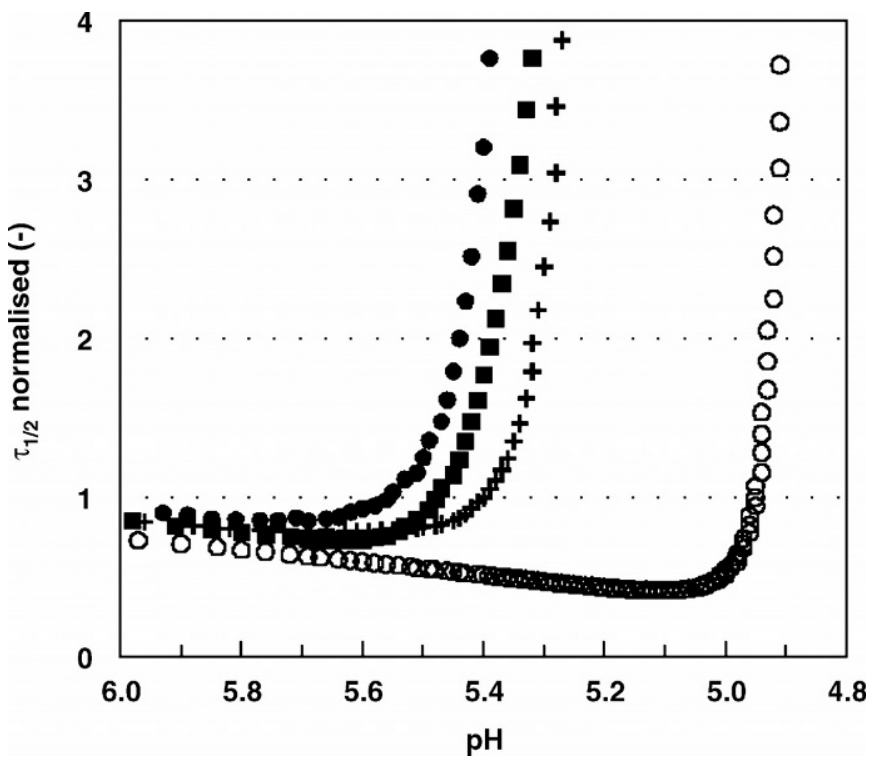

Figure 1. The acid-induced gelation of casein/whey protein mixtures as monitored by diffusion wave spectroscopy ( $\tau_{1 / 2}$ vs. pH); cas/

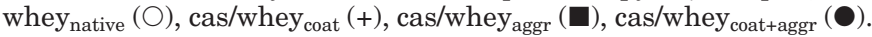

as native protein (cas/whey native ), as soluble aggregates

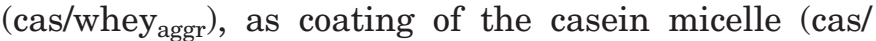
whey $\left.{ }_{\text {coat }}\right)$, and as a combination of aggregates and coating (cas/whey coat+aggr $_{\text {r }}$. The preparation method and composition of the milk systems are presented in Table 1 . The composition of the 4 casein-whey protein systems was determined prior to gelation by performing capillary electrophoresis analysis (results not shown). No interactions were observed between casein micelles and whey protein aggregates, which is in agreement with previous work (Alting et al., 2000). By mixing WPF milk with WPI, we were able to mimic the casein-whey protein concentrations and ratio of milk as well as to control the form in which the whey proteins were present. This allows us to systematically relate the acidinduced gelation properties to the form in which whey proteins are present in milk.

\section{Gelation Kinetics}

Acid-induced gelation of the 4 milk systems was monitored by DWS. The parameter $\tau_{1 / 2}$ (Vasbinder et al., 2001) reflects the mobility of the particles in solutioni.e., the casein micelles in milk-and is therefore a sensitive parameter for monitoring the clotting of casein micelles and the start of the subsequent gelation. On gelation, the measured relaxation time $\left(\tau_{1 / 2}\right)$ sharply increased. The $\mathrm{pH}$ at which this sharp increase occurred is defined as the gelation $\mathrm{pH}$. Figure 1 shows $\tau_{1 / 2}$ as a function of $\mathrm{pH}$. Cas/whey native showed a steady decrease of $\tau_{1 / 2}$ to a minimum at $\mathrm{pH} 5.0$ followed by a sharp rise in $\tau_{1 / 2}$. The $\tau_{1 / 2}$ traces of cas/whey coat $_{\text {and }}$ ans/whey aggr $_{\text {ag }}$ showed a large shift of the gelation $\mathrm{pH}$ to $\mathrm{pH}$ 5.5. The

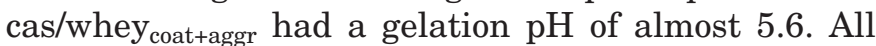
samples showed a sharp rise of ( $\tau$ upon further decrease of the $\mathrm{pH}$.

As is well known from the literature, the observed shift in gelation $\mathrm{pH}$ from 5.0 for unheated milk to 5.5 for heated milk is caused by whey protein denaturation (Vasbinder et al., 2001). The fact that a gelation $\mathrm{pH}$ of approximately 5.5 is observed for all 3 systems containing denatured whey proteins is remarkable. It reveals that the form in which the denatured whey proteins are present is not very relevant at the concentration present in milk. For cas/whey ${ }_{\text {coat }}$, the changed surface charge properties of the micelles are held responsible for the observed shift in gelation $\mathrm{pH}$ (Horne and Davidson, 1993; Vasbinder et al., 2001). Schorsch et al. (2001) and Lucey et al. (1998a) observed a similar shift in the gelation $\mathrm{pH}$ of milk systems containing all whey proteins in the form of aggregates (cas/whey ${ }_{\text {aggr }}$ ). A possible explanation is given by Schorsch et al. (2001): upon acidification, the whey protein aggregates form a network in which the casein micelles are entrapped. However, in a system containing 2 types of protein particles-i.e., casein micelles and whey protein aggregates-one would imagine 2 gelation phenomena, one at around $\mathrm{pH}=5.6$ (whey proteins) and one near $\mathrm{pH}=$ 5.0 (casein micelles). Nevertheless, the results in Figure 1 are indicative of a one-phase gelation process.

Gelation kinetics: concentration effects. To study the acid-induced gelation of the milk systems in more detail, we systematically varied the whey protein concentrations. Figures 2 and 3 show the acid-induced gelation of, respectively, cas/whey ${ }_{\text {aggr }}$ and cas/whey coat $_{\text {with }}$ a range of whey protein concentrations. The concentrations were varied between 0 and $0.44 \%(0.44 \%$ is the concentration present in fresh milk). An increase in aggregate concentration from 0 to $0.44 \%$ caused an abrupt shift of the gelation $\mathrm{pH}$ from 5.0 to 5.5 for the cas/whey ${ }_{\text {aggr }}$ system (Figure 2). Even $0.11 \%$ aggregates induced such a shift, although the further increase of $\tau_{1 / 2}$ was limited until $\mathrm{pH}$ 5.0, where $\tau_{1 / 2}$ showed a sharp rise. Increasing the concentration did not affect the gelation $\mathrm{pH}$ but made the slope of the $\tau_{1 / 2}-\mathrm{pH}$ curve steeper, indicating a stronger gel network. Increasing the concentration of whey proteins coating the casein micelle from 0 to $0.44 \%$ caused a gradual shift in gelation $\mathrm{pH}$ (Figure 3). The slope of the $\tau_{1 / 2}-\mathrm{pH}$ curves was similar for all concentrations. The system containing only casein micelles, which is identical to unheated milk, showed a very characteristic decrease in $\tau_{1 / 2}$ upon acidification to a minimum of about 0.5 . Due to coating of the casein micelle with whey proteins, this minimum disappeared at all concentrations studied. In the pres- 


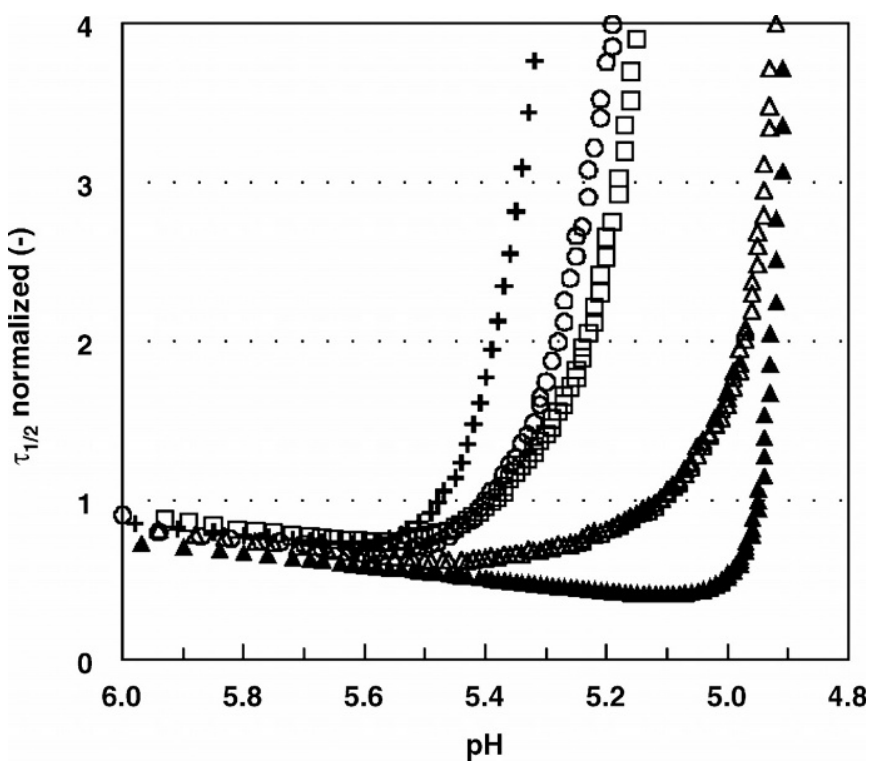

Figure 2. The acid-induced gelation of the cas/whey ${ }_{\text {aggr }}$ system as monitored by diffusion wave spectroscopy $\left(\tau_{1 / 2}\right.$ vs. $\left.\mathrm{pH}\right)$ with $0(\boldsymbol{\Delta})$, $0.11(\triangle), 0.22(\square), 0.33(\bigcirc)$, and $0.44 \%(+)$.

ence of aggregates, this minimum was still observed but with an earlier start of gelation. The results of Figures 2 and 3 indicate that although the behavior at whey protein concentrations present in milk $(0.44 \%)$ did not depend on the distribution of the whey proteins, the lower concentrations revealed a different mechanism. The expected 2-step gelation of cas/whey ${ }_{\text {aggr }}$ was observed at $0.11 \%$. At concentrations of $0.22 \%$ and higher, it became a one-step process. However, the steady decrease observed upon acidification at all concentrations of added whey protein aggregates revealed that there was no interaction between the casein micelles and the whey protein aggregates before the gelation $\mathrm{pH}$ was reached. Therefore, it seems that the start of gelation was induced by the whey protein aggregates around $\mathrm{pH} 5.5$, but that the casein micelles were already so sticky at this $\mathrm{pH}$ that they became entrapped in the gelation process as well. At $0.11 \%$, the amount of aggregates was not sufficient to incorporate the majority of the casein micelles in the gel, and therefore a 2 -step gelation was visible. The gradual shift in gelation $\mathrm{pH}$ of cas/whey $\mathrm{y}_{\text {coat }}$ with increasing concentration was in agreement with the idea that changing the surface charge of the casein micelle caused the shift in gelation $\mathrm{pH}$. More whey proteins coating the micelle increase the $\mathrm{pH}$ at which the micelle tends to neutrality with a maximum caused by the isoelectric point of $\beta$-LG. Therefore, further increasing the concentration showed no further shift, as can be seen at concentrations of 0.33 and $0.44 \%$.

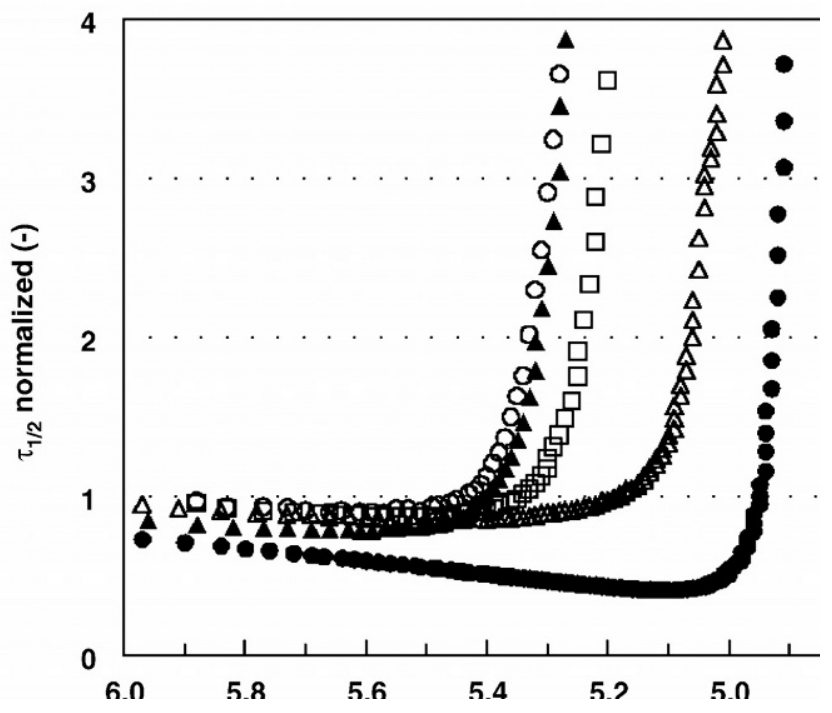

Figure 3. The acid-induced gelation of the cas/whey ${ }_{\text {coat }}$ system as monitored by diffusion wave spectroscopy $\left(\tau_{1 / 2}\right.$ vs. pH) with $0(\bullet)$, $0.11(\triangle), 0.22(\square), 0.33(\bigcirc)$, and $0.44 \%(\mathbf{\Lambda})$.

Summarizing, all forms of denatured whey protein contributed to the shift in gelation $\mathrm{pH}$. At $0.44 \%$, the whey protein concentration in milk, an apparently similar gelation behavior was observed for the different forms in which whey proteins are present. Thus, for the acid-induced gelation of heated milk, whey proteins may be present as separate aggregates or as a coating of the casein micelles. The gelation behavior of the milk seemed identical. However, experiments with lower concentrations revealed that another mechanism may be present as well.

\section{Gel Hardness}

The observed differences in the gelation behavior of the milk systems would very likely cause differences in the final gels. The different milk systems were slowly acidified by GDL at a temperature of $32^{\circ} \mathrm{C}$, resulting in milk gels with a final $\mathrm{pH}$ of 4.6 . Figures 4 and 5 show the results of large deformation studies of acid-milk gels. The resulting force-distance curves provided information on the modulus, the elasticity, and the gel hardness by, respectively, the slope of the curves and the displacement and force at rupture.

Figure 4 shows the force-distance curves of the 4 milk systems with $0.44 \%$ WPI in the absence and presence of NEM. Addition of NEM to the samples after heat treatment but prior to acidification prevented the formation of disulfide bridges, allowing us to determine the contribution of disulfide bridges formed during the gel state to the final gel hardness (Vasbinder et al., 


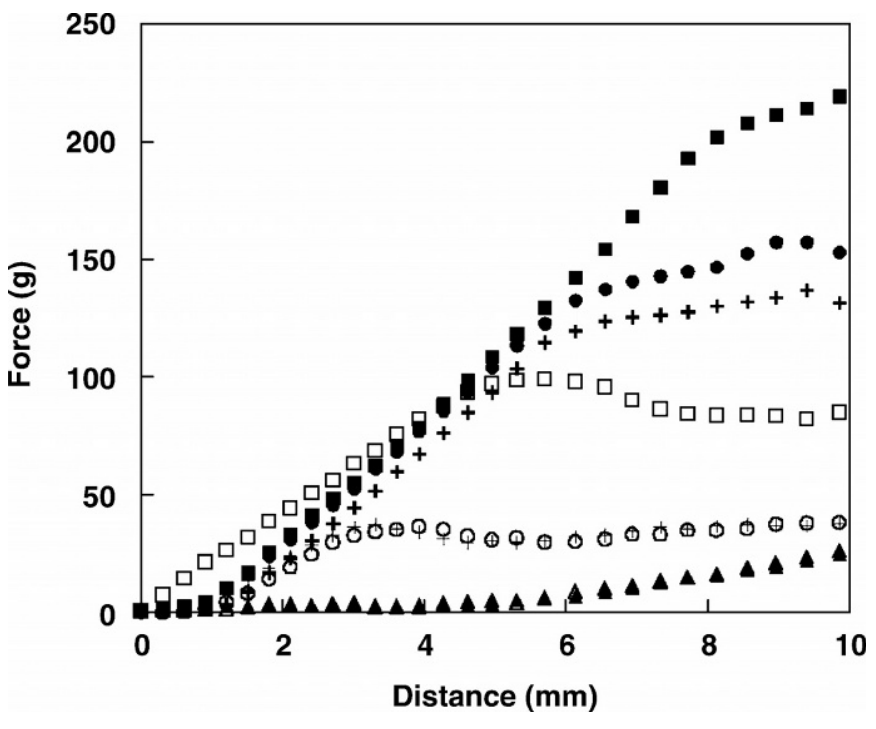

Figure 4. Large deformation properties of cas/whey native $(\mathbf{\Delta})$, cas/ whey $_{\text {coat }}(+)$, cas/whey coat+aggr $_{(}(\bigcirc)$, and cas/whey aggr $(\square)$. The closed symbols represent the force-distance curve of the gels formed in the absence of N-ethylmaleimide (NEM), and the open symbols represent the presence of NEM.

2003c). The gel hardness of all samples was determined after $24 \mathrm{~h}$ of incubation. Longer incubation times hardly affected the gel hardness of the milk systems either with or without NEM and are therefore not shown. Clear differences were observed among the samples, indicating the relevance of the form in which whey proteins are present in the milk prior to gelation. Cas/

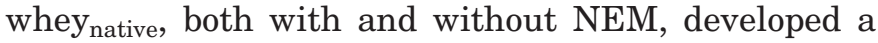
very low gel hardness. The 3 milk systems, cas/whey coat $_{\text {, }}$

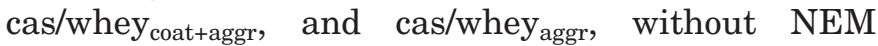
showed a sharp increase in the force with a very similar slope, but they leveled off at different gel hardness values, 130, 140, and $210 \mathrm{~g}$, respectively. Addition of NEM to these milk systems prior to gelation had a very clear effect on the development of the gel hardness: the 3 milk systems reached, respectively, 40, 40, and 100 g. However, the slope was hardly affected. Aggregates contributed strongly to the gel hardness if added alone; in combination with coating, the effect was less obvious. In all milk gels, development of disulfide bridges was an important factor for the final gel hardness obtained.

Lucey et al. (1998a) observed rather low storage modulus values for gels containing mainly soluble whey protein aggregates compared with gels prepared from normal heated milk. Although it is not possible to compare storage moduli quantitatively with data from the force-distance curves, the slope of a force-distance curve is related to the storage modulus of the gel. Qualitatively, this shows that the similar steep slopes we observed for all milk systems containing denatured whey

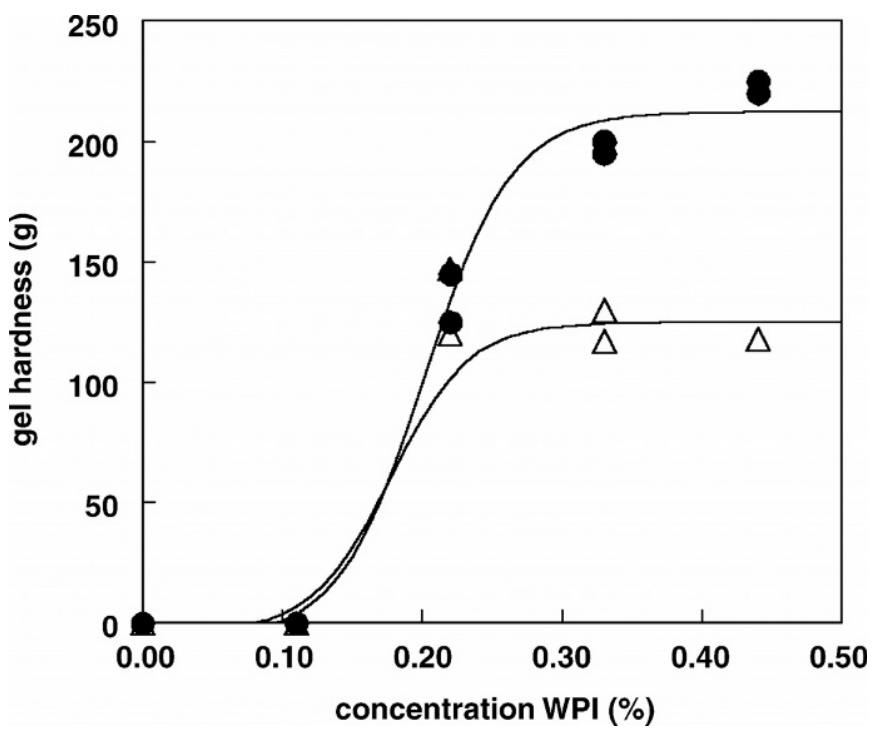

Figure 5. The gel hardness of cas/whey ${ }_{\text {coat }}(\triangle)$ and cas/whey ${ }_{\text {aggr }}$ ( ) with whey protein concentrations ranging from 0 to $0.44 \%$. The lines are drawn to guide the eye.

proteins are not in agreement with the differences observed in storage modulus by Lucey et al. (1998a). The cas/whey ${ }_{\text {aggr }}$ system showed the highest gel hardness of the milk systems, indicating that the presence of denatured whey proteins as aggregates is a very effective way to obtain firm gels. Vasbinder et al. (2003c) showed that in milk samples containing denatured whey proteins, still reactive thiol groups were exposed at ambient temperature conditions. However, these reactive thiol groups were not able to form crosslinks via the thiol-disulfide bond exchange reaction unless a locally increased protein concentration is induced within the gel network. Due to the low $\mathrm{pH}$ and the ambient temperature, the reactivity of the disulfide bridges is very low, but, nevertheless, the contribution observed was significant. In cas/whey $y_{\text {coat }}$ and cas/ whey $_{\text {coat+aggr }}$ both the whey protein-coated casein micelles and the whey protein aggregates contained denatured whey proteins and therefore reactive thiol groups. During the gel state, these reactive thiol groups will start to form disulfide bridges linking all particles together. However, the cas/whey aggr $_{\text {had only free thiol }}$ groups present on the whey protein aggregates. The most likely explanation for the relatively strong gel obtained and the clear contribution of disulfide bridge formation to the final gel hardness is the involvement of the casein micelles in the gelation process. It seems that the reactive thiol groups present in the aggregates can react with the disulfide bridges present in the casein micelles. The thiol-disulfide exchange reactions between whey protein aggregates and casein micelles strengthen the network structure. In Figure 5 the gel 

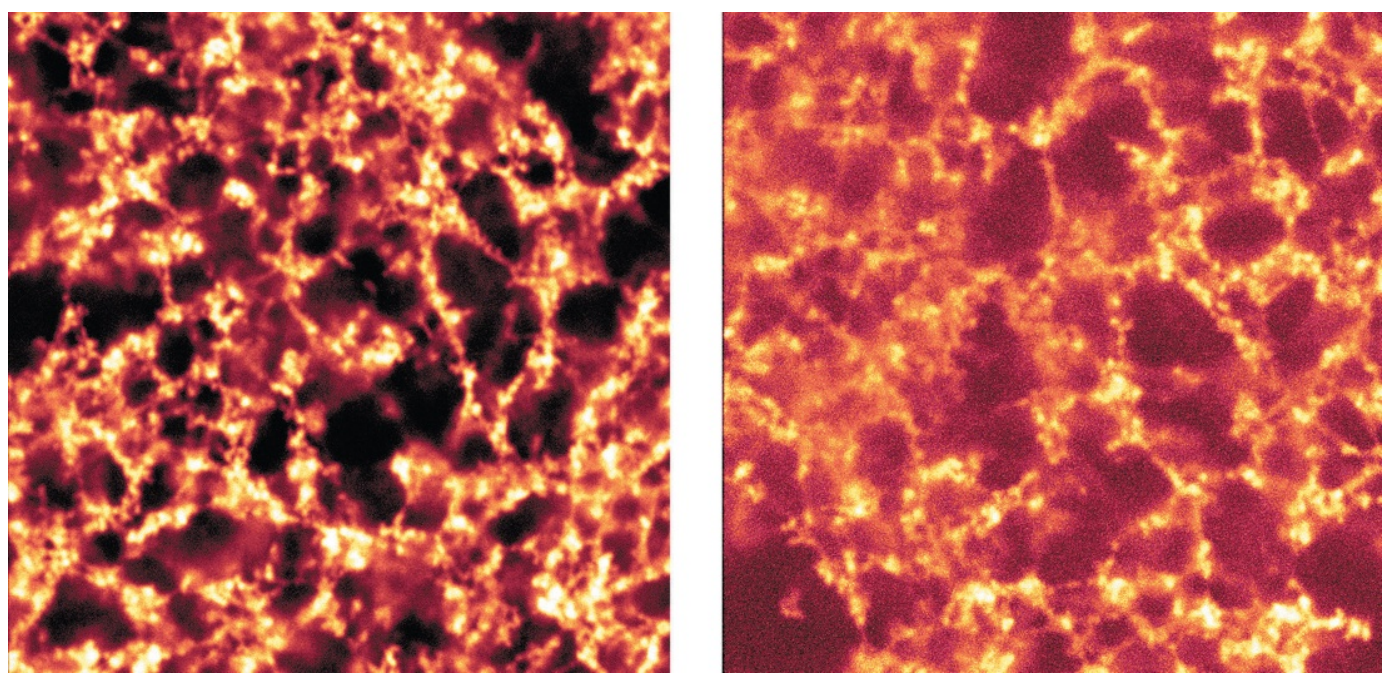

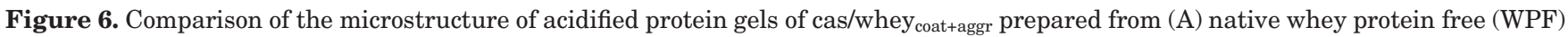
and native whey protein isolate (WPI) stained with free Rhodamine B and (B) WPF milk covalently labeled with Texas Red and WPI covalently labeled with Oregon Green. Image size: $40 \times 40 \mu \mathrm{m}$.

hardness is plotted as a function of the concentration of whey protein present either in the form of aggregates or as coating. For both systems, a clear increase in gel hardness was observed with increasing concentration from 0.11 to $0.22 \%$. The cas/whey coat $_{\text {was leveled off at }}$ a gel hardness of 120 with increasing concentration of whey proteins, whereas the cas/whey aggr showed a clear increase reaching a gel hardness of over 200 with $0.33 \%$ whey proteins. Experiments in the presence of NEM (not shown) showed a similar trend, as observed for $0.44 \%$, but much lower gel hardness was obtained for all concentrations. The results show that more than $0.11 \%$ of whey proteins is required to observe effects on the gel hardness, whereas the gelation kinetics is already affected at $0.11 \%$. Addition of aggregates to the milk is a much more effective way to increase the gel hardness than having a similar concentration of whey proteins coating the casein micelles.

\section{Microstructure}

The gel structure was monitored by using CSLM, a noninvasive microscopic technique that is very suitable for studying gels. In combination with covalent labeling techniques (Van de Velde et al., 2003), individual protein can be visualized in one sample. The microstructures of the protein gels formed with native proteins (stained with free Rhodamine B) and with covalently labeled proteins are given in Figure 6. A comparison of these images clearly shows that these 2 microstructures were highly comparable in terms of coarseness, strand thickness, and pore size. Therefore, we concluded that the covalent labeling of the individual milk proteins with Texas Red and Oregon Green had no effect on the microstructure of the gels formed by acidification with GDL. The strength of the labeling of individual milk proteins is demonstrated in Figure 7. The microstructures of the 2 individual milk proteins, Oregon Greenlabeled WPI (given in green in Figure 7A) and Texas Red-labeled WPF milk (given in red in Figure 7B) were recorded simultaneously in one sample (for more details of the technique, see Van de Velde et al. [2003]). The 2 individual images were combined in the overlay image (Figure 7C). Areas occupied by both proteins appear yellow in the overlay image. This overlay showed that the microstructure of this acidified protein gel was composed of a combined network of both casein micelles and whey proteins. Separate staining of the whey proteins and the casein micelles allowed the simultaneous study of the structure of both the whey protein and the casein fraction. This new and powerful approach was used to gain new insights in the gelation mechanism of mixed casein-whey protein systems.

Figure 8 shows images of the 4 milk gels on the left side of the Oregon Green-labeled whey protein fraction, in the middle of the Texas Red-labeled casein micelle fraction, and on the right side of the overlay of both pictures. The casein micelle fraction of cas/whey native showed a rather homogeneous structure with small pores, whereas the whey protein fraction was hardly structured. Heat treatment of the milk resulting in cas/ whey $_{\text {coat+aggr }}$ showed a more inhomogeneous structure with larger pores and a clearly structured whey protein phase. Gelation of cas/whey ${ }_{\text {aggr }}$ caused an even more inhomogeneous gel with larger pores and also a structured whey protein phase. Classifying the gels from 

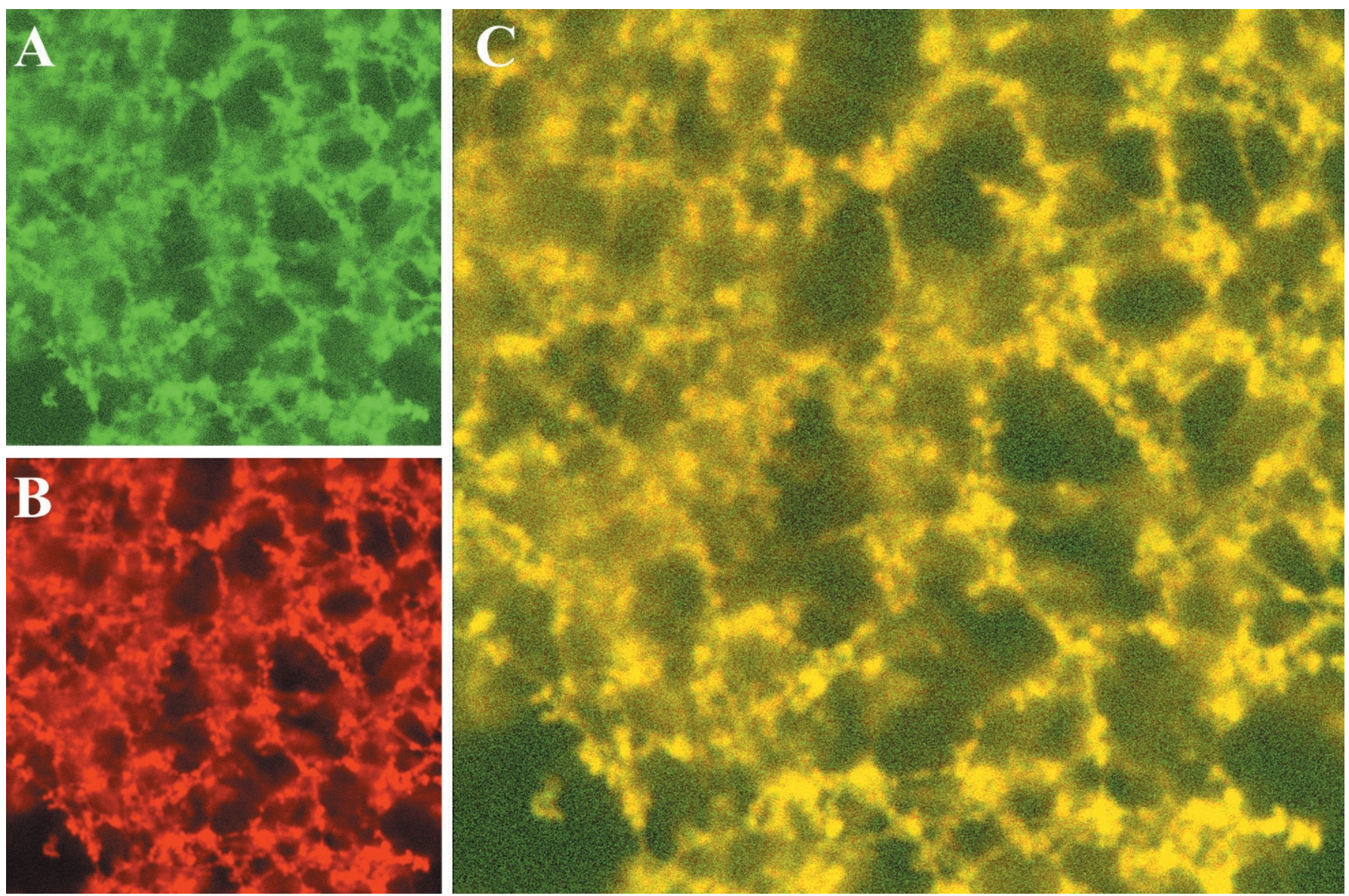

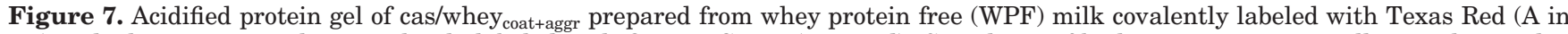
green) and whey protein isolate covalently labeled with Oregon Green (B in red). Complexes of both proteins appear yellow in the overlay (C). Image size: $40 \times 40 \mu \mathrm{m}$.

small to larger pores (as judged visually from the CSLM pictures) resulted in cas/whey native $_{<}$cas/whey coat $_{\text {cas/ }}$ cam

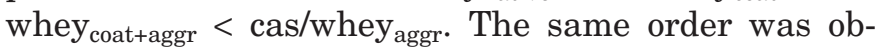
served in the gel hardness obtained. Apparently in these types of gels, a more inhomogeneous distribution of the proteins with large and thick strands resulted in firmer gels. In the milk systems containing denatured whey proteins, the structure of the whey protein phase is an overlay of the casein phase, revealing that both fractions interact simultaneously and no phase separation takes place. This was further checked by following the gelation of the 4 milk systems by CSLM with time (results not shown). This new approach of separately staining the 2 protein fractions revealed that, in the 3 milk systems containing denatured whey proteins, the structure formation started at the same $\mathrm{pH}$ for both the whey and the casein fraction. These results were clearly understandable for the cas/whey coat $_{\text {cas }}$ the casein and whey protein fraction were already covalently bound prior to gelation, therefore also resulting in a mixed casein-whey protein gel. It was less obvious for the system with added whey protein aggregates, cas/ whey $_{\text {aggr, }}$ as the casein and whey protein fraction are not linked prior to gelation. However, it confirmed the one-phase gelation of cas/whey aggr $_{\text {as }}$ observed by DWS. Apparently, the aggregates were able to interact with the casein fraction around the $\mathrm{pH}$ of gelation (5.5), probably due to loss of steric repulsion caused by approaching its $\mathrm{pI}$.

\section{CONCLUSION}

This study has shown the key role of the denatured whey protein composition in milk to the acid-induced gelation properties and final gel characteristics. Normal heated milk contains about 30\% aggregates and 70\% coating. Milk systems with all whey proteins associated

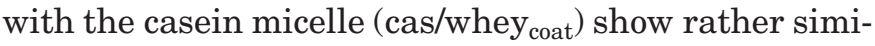
lar results compared with normal heated milk. The results obtained with cas/whey ${ }_{\text {aggr }}$ showed that structur- 

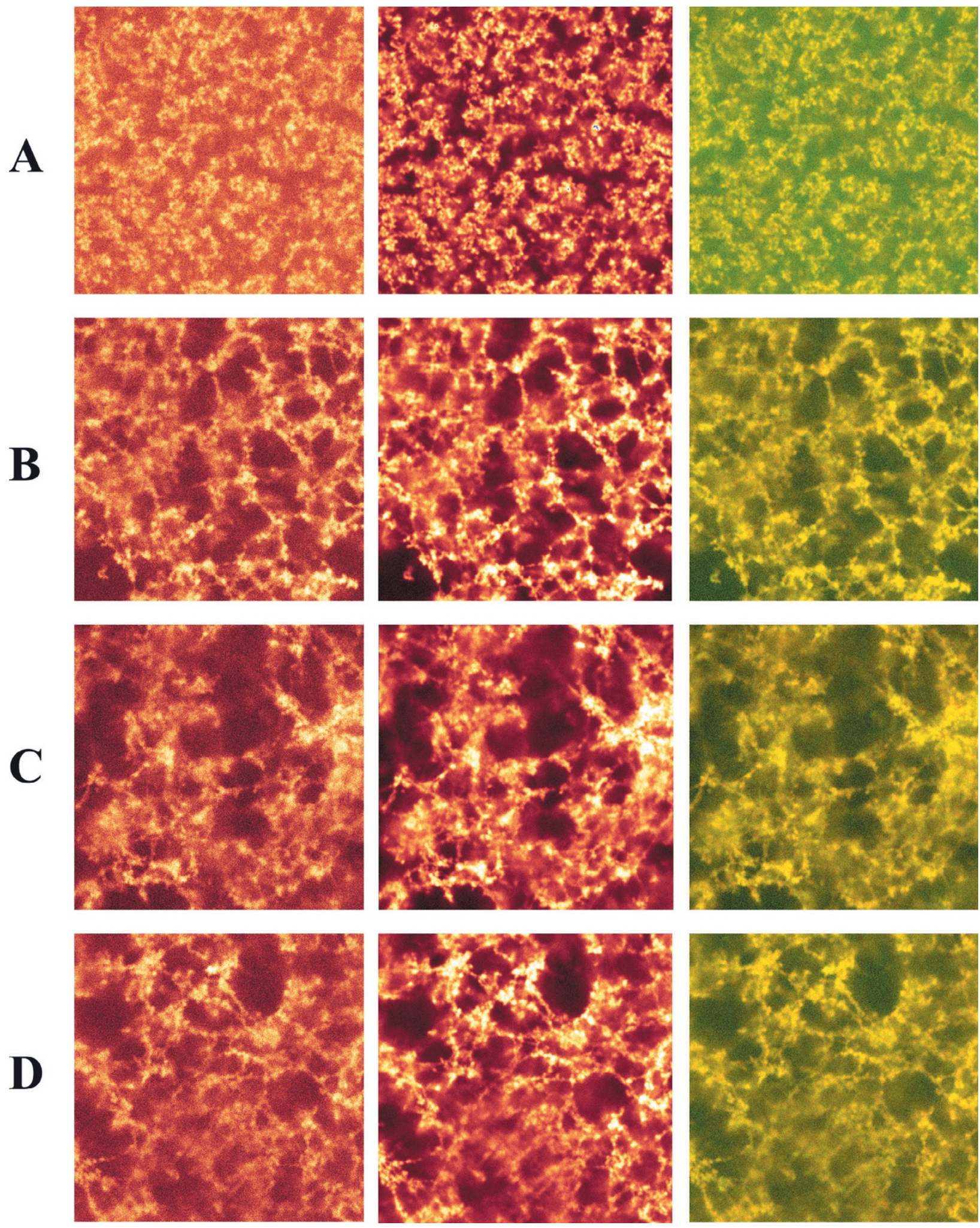

Figure 8. Confocal scanning laser microscopy(CSLM) images of acidified protein gels made of cas/whey native $_{\text {(A) }}$, cas/whey coat+aggr $_{\text {(B) }}$, cas/

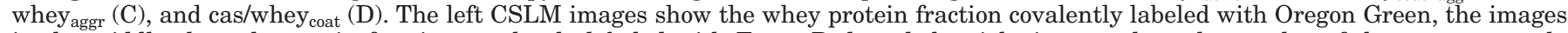
in the middle show the casein fraction covalently labeled with Texas Red, and the right images show the overlay of the two separately labeled proteins. Image size: $40 \times 40 \mu \mathrm{m}$. 
ing the denatured whey proteins in whey protein aggregates is the most effective way to obtain firm gels. Even though the aggregates are not associated with the casein micelles in the milk prior to gelation, they seem to be able to interact at $\mathrm{pH} 5.5$, involving the casein micelles in the gelation process. Disulfide bridge formation and rearrangement appear to play an important role during the gel state of the 3 milk systems containing denatured whey proteins-i.e., cas/wheyaggr, cas/whey ${ }_{\text {coat }}$, and cas/whey aggr+coat. The newly developed CSLM approach allows the visualization of the individual proteins during the gelation process. This revealed that, in the 3 heated systems, the 2 proteins start to form a structured network at the same $\mathrm{pH}$. It was clearly demonstrated that the aggregates form disulfide bonds in the gel state. These results showed that inducing more aggregates in normal heated milk might be a very effective way to increase the gel hardness. This is, for example, possible by slightly increasing the $\mathrm{pH}$ prior to heating (Vasbinder, 2003a). Summarizing, this work highlights the role of denatured whey proteins during acid-induced gelation and suggests routes to improve the effective use of whey proteins.

\section{ACKNOWLEDGMENTS}

The authors gratefully acknowledge Arno Alting (NIZO food research) for helpful discussions on the thiol-disulfide exchange reactions.

\section{REFERENCES}

Alting, A. C., R. J. Hamer, C. G. de Kruif, and R. W. Visschers. 2000. Formation of disulphide bonds in acid-induced gels of pre-heated whey protein isolate. J. Agric. Food Chem. 45:1108-1115.

Bourne, M. C. 1978. Texture profile analysis. Food Technol. 3:6266,72 .

Dannenberg, F., and H. G. Kessler. 1988. Effect of denaturation of $\beta$-lactoglobulin on texture properties of set style nonfat yoghurt. 2. Firmness and flow properties. Milchwissenschaft 43:700-704.
Haugland, R. P. 2002. Handbook of Fluorescent Probes and Research Chemicals. Molecular Probes Inc., Eugene, OR.

Heertje, I., J. Visser, and P. Smits. 1985. Structure formation in acid milk gels. Food Microstructure 4:267-277.

Horne, D. S., and C. M. Davidson. 1993. Influence of heat treatment on gel formation in acidified milks, protein and fat globule modification. Pages 267-276 in Proc. IDF Seminar. IDF, Brusssels, Belgium.

Lucey, J. A., C. Tet Teo, P. A. Munro, and H. Singh. 1997. Rheological properties at small (dynamic) and large (yield) deformations of acid gels made from heated milk. J. Dairy Res. 64:591-600.

Lucey, J. A., M. Tamehana, H. Singh, and P. A. Munro. 1998a. Effect of interactions between denatured whey proteins and casein micelles on the formation and rheological properties of acid skim milk gels. J. Dairy Res. 65:555-567.

Lucey, J. A., C. Tet Teo, P. Munro, and H. Singh. 1998b. Microstructure, permeability and appearance of acid gels made from heated skim milk. Food Hydrocolloids 12:159-165.

Oldfield, D. J., H. Singh, M. W. Taylor, and K. N. Pearce. 2000. Heatinduced interactions of $\beta$-lactoglobulin and $\alpha$-lactalbumin with the casein micelles in $\mathrm{pH}$-adjusted skim milk. Int. Dairy J. 10:509-518.

Schorsch, C., D. K. Wilkins, M. G. Jones, and I. T. Norton. 2001. Gelation of casein-whey mixtures: Effects of heating whey proteins alone or in the presence of casein micelles. J. Dairy Res. 68:471-481.

Singh, H., M. S. Roberts, P. A. Munro, and C. T. Teo. 1996. Acidinduced dissociation of casein micelles in milk: Effect of heat treatment. J. Dairy Sci. 79:1340-1346.

Van de Velde, F., F. Weinbreck, M. W. Edelman, E. Van der Linden, and R. H. Tromp. 2003. Visualisation of biopolymer mixtures using Confocal Scanning Laser Microscopy (CSLM) and covalent labelling techniques. Colloids Surfaces B: Biointerfaces 31:159168.

Van Vliet, T., and C. J. A. M. Keetels. 1995. Effect of preheating of milk on the structure of acidified milk gels. Neth. Milk Dairy J. 49:27-35.

Vasbinder, A. J., and C. G. de Kruif. 2003a. Casein-whey protein interactions in heated milk: The influence of $\mathrm{pH}$. Int. Dairy J. 13:669-677.

Vasbinder, A. J., A. C. Alting, and C. G. de Kruif. 2003b. Quantification of the heat-induced casein-whey protein interactions in milk and it relation to gelation kinetics. Colloids Surfaces B: Biointerfaces 31:115-123.

Vasbinder, A. J., A. C. Alting, R. W. Visschers, and C. G. de Kruif. 2003c. Texture of acid milk gels: Formation of disulfide crosslinks during acidification. Int. Dairy J. 13:29-38.

Vasbinder, A. J., P. J. J. M. van Mil, A. Bot, and C. G. de Kruif. 2001. Acid-induced gelation of heat-treated milk studied by diffusing wave spectroscopy. Colloids Surfaces B: Biointerfaces 21:245250 . 